\title{
Fingerprinting of Leafhoppers on Medicinal and Aromatic Plants in Egypt Using ISSRs \\ Helmi A. ${ }^{1}$; A. A. Sharaf ${ }^{2}$ and Heba E. Ibrahim ${ }^{3}$ \\ 1- Plant Protec. Dept., Fac. of Agric. Ain Shams Univ. Cairo, 11241, Egypt. \\ 2- Genetic Dept., Fac. of Agric. Ain Shams Univ., Cairo, 11241, Egypt ; Biology Centre (ASCR), inst., of Parasitology, 37005, České Budějovice, Czech Republic. \\ 3- Plant Protec. Rese. Inst., Agric. Res. Center, Giza, Egypt.
}

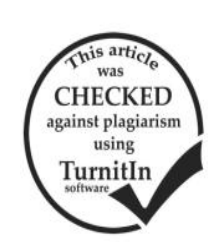

\section{ABSTRACT}

Leafhoppers are one of the most important agricultural insect pests. Traditional morphological criterion for leafhoppers identification depending on the presence of males only. So, Inter Simple Sequence Repeats (ISSRs) were used to find diagnostic markers for fingerprinting fifteen leafhoppers species collected from different medicinal and aromatic plants in Egypt. Seven ISSRs primers were successfully produced 72 bands those could be used to differentiate the fifteen different leafhopper species. Also different amplified bands with 65 diagnostic morphological characters were used to determine the phylogenetic relationship among the different species; that divided into two main clusters. ISSR-PCR technique could be successfully used with morphological characters to fingerprint and identify these leafhopper species using any life stage

Keywords: Leafhoppers, fingerprinting, morphology, ISSRs, identification, markers, microsatellites, phylogeny.

\section{INTRODUCTION}

Leafhoppers (Hemiptera: Auchenorrhyncha: Cicadellidae). Family Cicadellidae is a globallydistributed group of sap-feeding insects that contains 20000 described species (Dietrich, 2013). They suck plant sap from the xylem, phloem or mesophyll cells (Knight 1983) causing a drying of the leaf tissue. Leafhoppers release their toxic saliva into the plant tissue causing leaves turn yellow, their edges dry and their tissue dies "hopper burn." and the plant becomes stunted (Ebesu 2004) and cause serious plant injury either directly through feeding or indirectly by transmitting plant pathogens including viruses, bacteria and phytoplasmas (Weintraub and Beanland, 2006). Identification of leafhopper species is mainly based on adult male especially genitalia characters. While another additional characters, such as coloring, details in head and elytral characters are also important in the identification on generic level (Herakly 1970). Identification of Cicadomorphan species is difficult because of their tremendous diversity and the paucity of comprehensive identification keys (Dietrich, 2005). The classical taxonomy proves its reliability but has limitations, such as, requirement of adult specimens especially males for morphological analysis. As well as morphology and high genetic diversity poses problems in phylogenetic studies of insects (Pires and Marinoni, 2010). To solve these problems, DNA based markers have been adopted and are increasingly used as molecular markers for fingerprinting and detecting phylogeny among species (De León and Jones, 2004; De León et al., 2004; De Mandal et al., 2014; Sreejith and Sebastian, 2015).The present work aims at fingerprinting and detecting phylogenetic relationships among different leafhopper species infest medicinal and aromatic plants in Egypt.

\section{MATERIALS AND METHODS}

\section{Survey of leafhopper species:}

Field survey of leafhopper species was carried out during three successive years from 2013 to 2015 in different localities and different medicinal and aromatic plants of Egypt.
Samples were caught using the sweep net and aspirator from each plant then were transferred to the laboratory where individuals of leafhopper were mounted on slides for identification using available keys. Each species was put in especial tube and preserved at $-20^{\circ} \mathrm{C}$ until molecular analysis.

\section{ISSR-PCR Analysis:}

\section{a. DNA Extraction}

Fifteen different species of leafhoppers samples were collected and extracted DNA from them. Animal tissues were ground under liquid nitrogen to a fine powder, and then bulked DNA extraction was performed using DNeasy Mini Kit (QIAGEN).

\section{b. Polymerase Chain Reaction (PCR)}

PCR amplification was performed using seven Inter Simple Sequence Repeat (ISSR) (Table 1).

Table 1. list of primers, names and their nucleotide sequences used to determine fingerprinting of leafhopper species using ISSR- PCR technique.

\begin{tabular}{|c|c|c|}
\hline No & Name & Sequence \\
\hline 7 & $14 \mathrm{~A}$ & 5 CТC ТСТ СТС ТСТ СТС TTG 3 \\
\hline 2 & 44B & $5^{\prime}$ СТС ТСТ СТC ТСТ СТС ТGC $3^{\prime}$ \\
\hline 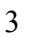 & HB-08 & $5^{\prime}$ GAG AGA GAG AGA GG $3^{\prime}$ \\
\hline 4 & HB-10 & $5^{\prime}$ GAG AGA GAG AGA CC $3^{\prime}$ \\
\hline 5 & HB-12 & $5^{\prime}$ CAC CAC CAC GC $3^{\prime}$ \\
\hline 6 & HB-14 & $5^{\prime}$ CTC CTC CTC GC $3^{\prime}$ \\
\hline 7 & HB-15 & 5' GTG GTG GTG GC 3' \\
\hline
\end{tabular}

Amplification was conducted in $25 \mu \mathrm{L}$ reaction volume containing the following reagents: $2.5 \mu \mathrm{L}$ of dNTPs $(2.5 \mathrm{mM}), 2.5 \mu \mathrm{L} \mathrm{Mgcl}_{2}(2.5 \mathrm{mM})$, and $2.5 \mu \mathrm{L}$ of $10 \mathrm{x}$ buffer, $3.0 \mu \mathrm{L}$ of primer $(10 \mathrm{pmol}), 3.0 \mu \mathrm{L}$ of template DNA $(25 \mathrm{ng} / \mu \mathrm{L}), 1 \mu \mathrm{L}$ of Taq polymerase $(1 \mathrm{U} / \mu \mathrm{L})$ and $10.5 \mu \mathrm{L}$ of sterile $d d \mathrm{H}_{2} \mathrm{O}$. The DNA amplifications were performed in an automated thermal cycle (model Techno 512). The PCRs were programmed for one cycle at $94^{\circ} \mathrm{C}$ for 4 min followed by 45 cycles of $1 \mathrm{~min}$ at $94^{\circ} \mathrm{C}, 1 \mathrm{~min}$ at $57^{\circ} \mathrm{C}$, and $2 \mathrm{~min}$ at $72^{\circ} \mathrm{C}$. The reaction was finally stored at $72^{\circ} \mathrm{C}$ for $10 \mathrm{~min}$. Amplified products were size-fractioned using ladder marker100 bp (1000, 900, 800, 700, 60, 500, 400, 300, 200 and $100 \mathrm{bp}$ ) by electrophoresis in $1.5 \%$ agarose gels in TBE buffer at $120 \mathrm{~V}$ for $30 \mathrm{~min}$. The bands were visualized by ethidium bromide under UV florescence and photographed. 
Densitometry Scanning and Analysis:

All gels resulted from DNA fingerprints, were scanned using Bio-Rad GelDoc2000 to calculate the pair-wise differences matrix and plot the dendrogram among different leafhopper species.

\section{Phylogenetic relationship among different \\ leafhopper species:}

Diagnostic Morphological characters:

For determining the phylogenetic relationships among those leafhopper species, sixty-five diagnostic morphological characters were compiled according to the previous mentioned identification keys in addition some diagnostic characters were added according to this work (Table 2).

All specimens used for this study were recently collected. The use of this fresh material allowed for thorough manipulation under the binocular for morphological data obtained and for extraction of genetic material.

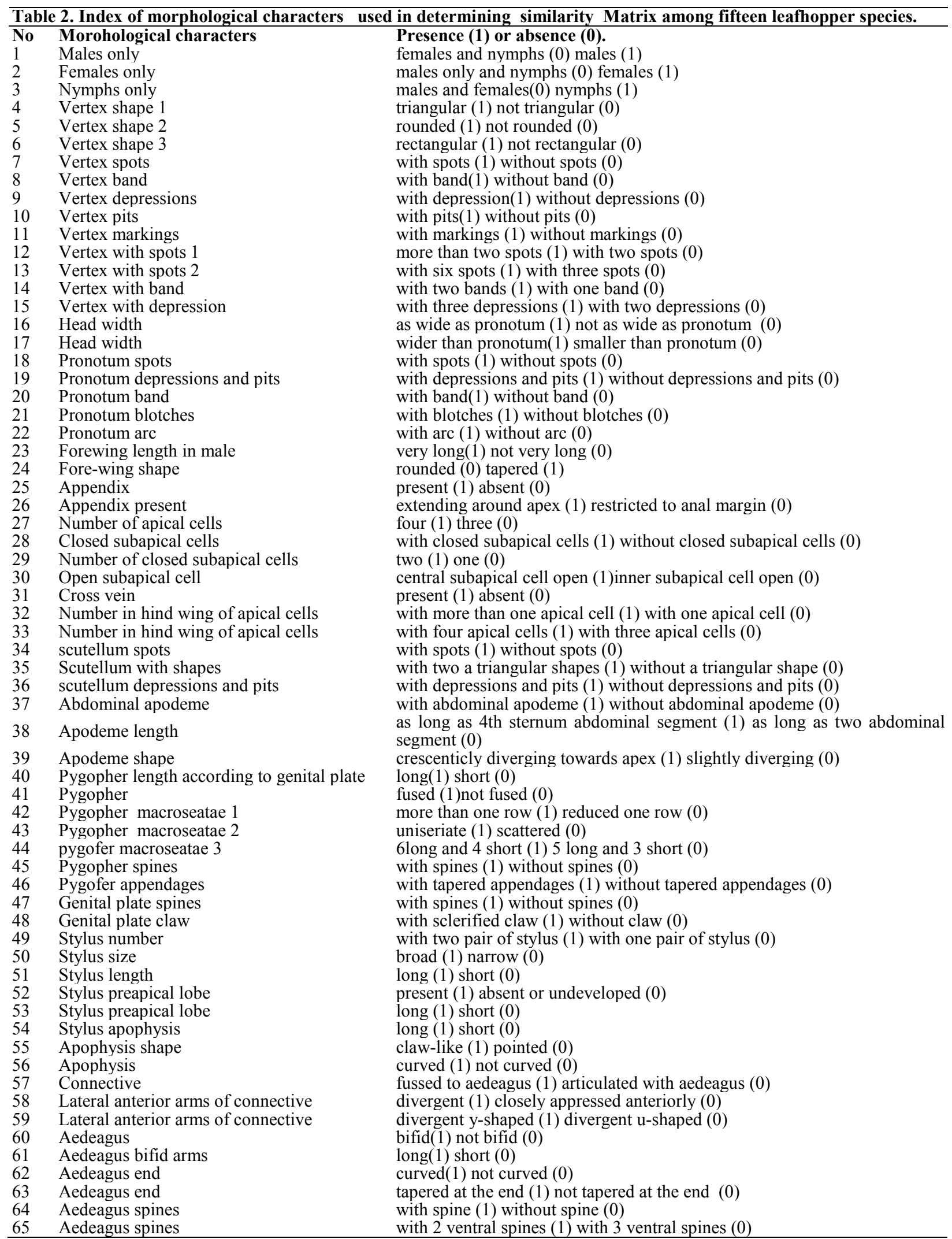


Currently only males can be identified to species. Sometimes, females and nymphs specimens were examined and identified to genus by Dr. Christopher H. Dietrich of the Illinois Natural History Survey, USA.

ISSR-PCR Data analysis:

The similarity matrix was done using Gel Works ID Advanced Software UVP-England Program. The relationships among genotypes as revealed by dendrogram was done using SPSS Windows (Version 10) Program. DICE computer package was used to calculate the pairwise difference matrix and plot the phenogram among species or genus (Yang and Quiros, 1993).

\section{RESULTS AND DISCUSSION}

After surveying of leafhoppers individuals from different medicinal and aromatic plants and different localities, they subjected to identification using available keys.

Fifteen leafhopper species were identified and listed alphabetically by scientific name in (Table 3 ).

Initial screening of many numbers of ISSR markers on fifteen samples of cicadellid resulted in seven ISSR primers those produced informative and polymorphic products resolvable by agarose gel electrophoresis (Fig. 1). These seven markers were amplified 73 bands as follows:

Table 3. Fifteen leafhopper species on medicinal and aromatic plants in Egypt arranged according to their subfamilies alphabetically.

\begin{tabular}{|c|c|c|}
\hline Subfamily & Tribe & \\
\hline \multirow{12}{*}{ Deltocephalinae } & & Aconurella prolix (Lethierry) \\
\hline & Chiasmini & Exitianus pondus Ross \\
\hline & & Nephotettix modulates Melichar \\
\hline & Hecalini & Parabolocratalis sp. Evans \\
\hline & & Balclutha frontalis (Ferrari) \\
\hline & & Cicadulina bipunctella zeae \\
\hline & Macrostelini & China \\
\hline & & Cicadulina chainai Ghauri, \\
\hline & & Macrosteles sexnotatus (Fallen) \\
\hline & Opsiini & Orosius albicinctus Distant \\
\hline & Paralimnini & $\begin{array}{l}\text { Psammotettix alienus } \\
\text { (Dahlbom) }\end{array}$ \\
\hline & Scaphoideini & Neolimnus aegyptiacus \\
\hline Typhlocybinae & Typhlocybini & $\begin{array}{l}\text { Empoasca decipiens Paoli } \\
\text { Eupteryx cypria Ribaut }\end{array}$ \\
\hline Ulopinae & Ulopini & $\begin{array}{l}\text { Megulopa sahlbergorum } \\
\text { Lindberg }\end{array}$ \\
\hline Megophthalminae & Agalliini & Austroagallia sp. Evans \\
\hline
\end{tabular}

14-A Primer:

The results of ISSR analysis using 14A primer indicated that this primer produced seven bands with molecular sizes ranged between 1337-342bp. All of them were polymorphic $(100 \%)$ except band with molecular size of $1337 \mathrm{bp}$. which can be assigned as a positive marker for C. chinai. No common band was detected by this primer. The highest number of bands were four which occurred in five species (E. pounds, $C$. chinai, A. prolixa, N. modulates and $P$. alienus). No band was recorded for $N$. aegyptiacus.

\section{4-B Primer:}

The results of ISSR marker analysis by using 44B primer showed that this primer amplified ten bands with molecular sizes ranged between 919 - 224bp. Nine of them were polymorphic $(90 \%)$. On the other hand, band with molecular size of 384 bp. was monomorphic (common). The band with molecular size of $307 \mathrm{bp}$. can be assigned as a negative marker for $N$. aegyptiacus. The highest band numbers were nine recorded in $N$. modulates while the lowest band numbers were three detected in M. sahlbergorum.

\section{HB-08 Primer:}

The results of ISSR analysis using HB-08 primer were indicated that this primer amplified ten bands with molecular sizes ranged between $734-$ $174 \mathrm{bp}$. Nine of them were polymorphic (90\%). Band with molecular size of $689 \mathrm{bp}$. was unique so can be assigned as a positive marker for A. prolixa. While bands with molecular sizes of 332 and $281 \mathrm{bp}$. assigned as negative markers for Austroagallia sp. and $C$. bipunctella zeae, respectively. No common band was detected by this primer. The highest number of bands was eight detected in E. pondus, N. aegyptiacus, E. cypria, M. sexnotatus, B. frontalis, C. chinai and $O$. albicinctus; while the lowest number of bands was three bands detected in $N$. modulates.

\section{HB-10 Primer:}

This primer amplified nine fragments with molecular sizes ranged between $946-288 \mathrm{bp}$. All of them were polymorphic $(100 \%)$. The highest number of bands was 6 bands detected in A. prolixa, E. decipiens, $N$. modulates, $P$. alienus and $M$. sahlbergorum, while the lowest band numbers was two bands in Austroagallia sp., N. aegyptiacus and C. bipunctella zeae. No common or unique band was amplified by this primer.

\section{HB-12 Primer:}

This primer amplified 12 bands with molecular sizes ranged between 1672 - 167 bp. Six of them were polymorphic. Band with molecular size of $1672 \mathrm{bp}$. can be assigned as a positive marker and unique band for Parabolocratalis sp. Also three bands with molecular sizes of 759, 670 and 613bp can be assigned as positive markers and unique bands for $C$. chinai. Bands with molecular sizes of 364 and $276 \mathrm{bp}$. could be assigned as positive markers and unique bands for A. prolixa. and $P$. alienus, respectively. The highest number of bands was six detected in $P$. alienus, while the lowest number of band was one band was detected on Austroagallia sp., E. pondus, $N$. aegyptiacus, E. cypria, $M$. sexnotatus, $B$. frontalis, C.bipunctella zeae and O. albicinctus.

\section{HB-14 Primer:}

This primer amplified ten bands with molecular sizes ranged between $922-252 \mathrm{bp}$. Eight of them were polymorphic $(80 \%)$ while bands with molecular sizes of 922and 294bp. were unique where these bands can be assigned as positive markesrs for Austroagallia sp. and C. bipunctella zeae respectively. The highest number of bands was six detected in Austroagallia sp. while only one band was detected in E. pondus. No common bands were detected. 


\section{HB-15 Primer:}

This primer amplified fifteen bands with molecular sizes ranged between $1542-315 \mathrm{bp}$. Nine of them were polymorphic while bands with molecular sizes of 980 and $538 \mathrm{bp}$. were common bands. On the other hand, band with molecular size of $315 \mathrm{bp}$. can be assigned as a negative marker for Austroagallia sp. The highest number of bands was nine detected in $A$. prolixa and $N$. modulates, while the lowest number of bands was three detected in Austroagallia sp.

From the above mentioned results it could be stated that six primers out of the seven tested primers had unique bands with certain molecular sizes and can be assigned to identify 7 species out of 15 cicadellid species as follows:

$14-\mathrm{A}$ primer at molecular size $1337 \mathrm{bp}$. and HB-12 primer at molecular sizes 759, 670 and 613bp. can be assigned Cicadulina chinai. While 44-B primer at 384 bp. could be used to identify Neolimnus aegyptiacus. Also, HB-08 primer at $689 \mathrm{bp}$. and HB-12 primer at $364 \mathrm{bp}$. could be assigned Aconurella prolixa. HB-12 primer at 1672 bp. and 276bp. could be assigned Parabolocratalis sp. and Psammotettix alienus, respectively. While HB-14 primer at $922 \mathrm{bp}$. and HB-15 primer at $315 \mathrm{bp}$. could be identified Austroagallia sp. Also, HB-14 primer at 294bp. identified Cicadulina bipunctella zeae.

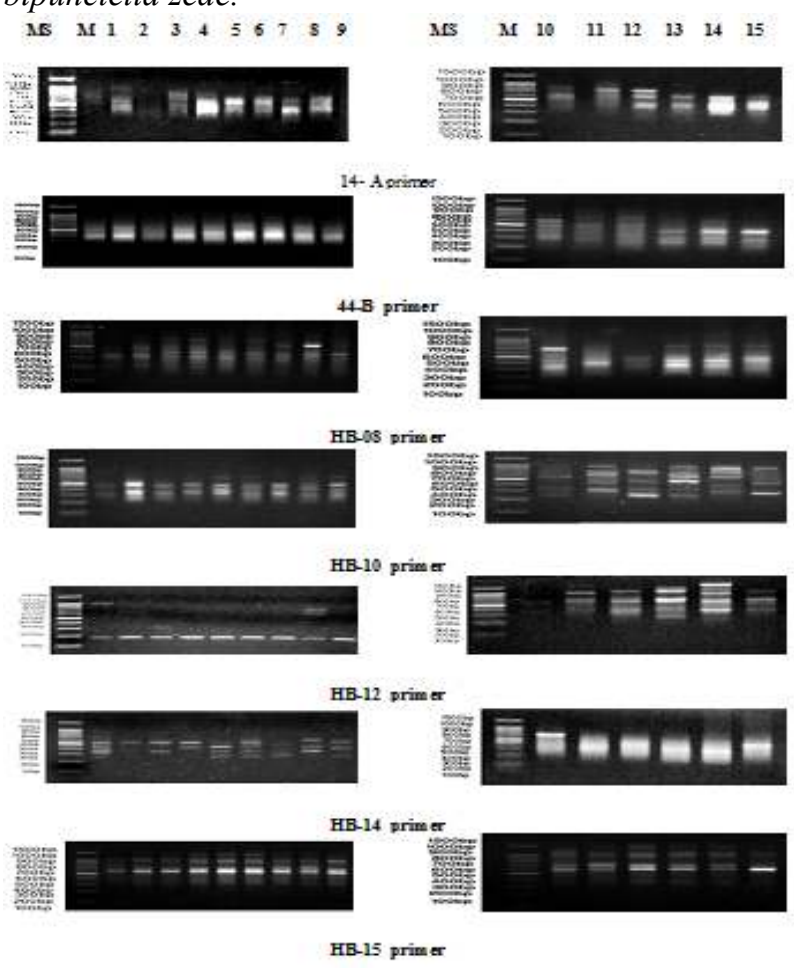

Fig.1. The ISSR-PCR banding patterns of fifteen leafhopper species amplified by seven primers. MS, molecular size; M, marker; 1, Austroagallia sp.; 2, $E$. pondus; $3, N$. aegyptiacus; 4, E. cypria; 5, M. sexnotatus; 6, B. frontalis; 7, C. bipunctella zeae; 8, C. chainai; 9, O. albicinctus; 10, A. prolix; 11, E. decipiens; 12, N. modulates; 13, P. alienus; 14, Parabolocratalis sp.; 15, M. sahlbergorum.
Phylogenetic relationships and similarity matrix based on Morphological Characters and Molecular (ISSR-PCR) analysis:

Genetic similarities and Phylogenetic relationships among the fifteen leafhopper species were based on data gathered from analysis of 65 diagnostic morphological characters and seven molecular markers ISSSR-PCR (Table 4). The most close relationship was scored among C. bipunctella zeae and C. chinai. The highest similarity value was $80.3 \%$ among the previous two species and the lowest similarity value was $26.3 \%$ among $C$. bipunctella zeae and M. sahlbergorum individuals.

The phylogenetic dendrogram in Figure 2 branched into two main clusters the first cluster divided into two sub-clusters. The first sub-cluster separated into two sub-sub-clusters. The first sub-sub-cluster, $E$. decipiens was found alone. The second sub-sub-cluster divided into two clades within the first clade $A$. prolixa was standed alone while the second clade included $P$. alienus and $N$. modulates. The second sub-cluster included M. sahlbergorum and Parabolocratalis sp. which were grouped together. The second cluster separated into two sub-clusters. The first sub-cluster Austroagallia sp. was located alone. Meanwhile, the second sub- cluster separated into two sub-sub-clusters. The first sub-sub-cluster N. aegyptiacus and E. pondus were grouped together. The second sub-sub-cluster divided into two clade the first clades, contained $M$. sexnotatus and $E$. cypria which were grouped together and the second clade divided into two sub-clades. The first sub-clade $O$. albicinctus and $B$. frontalis were grouped together. The second sub-clade contained $C$. chinai and C. bipunctella zeae.

In addition the combined data markers represented in Table 4 could be concluded that the both criteria could be used to discriminate between leafhopper species that belong to the same genus. Also it could be successfully separated between the fourteen genera that included the fifteen leafhopper species.

Inter Simple Sequence Repeats (ISSRs or 'microsatellites') has shown much promise for the study of the plant population (Clausing et al., 2000; Hess et al., 2000). Also ISSR-primers have been widely used for DNA fingerprinting and assessing genetic diversity in closely related germplasm (Blair et al., 1999; Charters et al., 1996). While in animals, ISSR technique broadly used as intraspecific markers for animal populations (Abbot, 2001; Ardeh, 2013; De León and Jones, 2004; De León et al., 2004a\& b; Kostia et al., 2000 and Reddy et al., 1999). On the other hand few researchers used ISSR markers as interspecific markers (Helmi and Khafaga, 2011 and Luque et al., 2002). However study of ISSRs used only to detect DNA polymorphisms in Homalodisca coagulata populations (De León and Jones, 2004; De León et al., 2004). ISSRprimers can be used as universal primers, which do not need to be adapted to individual species like in microsatellite marker. Consequently, the production of large numbers of fragments, reproducibility, and low cost are considered as advantages of the ISSR primers (Moreno et al., 1998 and Weng et al., 2007). 
Table 4. Similarity matrix percentages among fifteen leafhopper species based on both diagnostic morphological characters and ISSRs markers

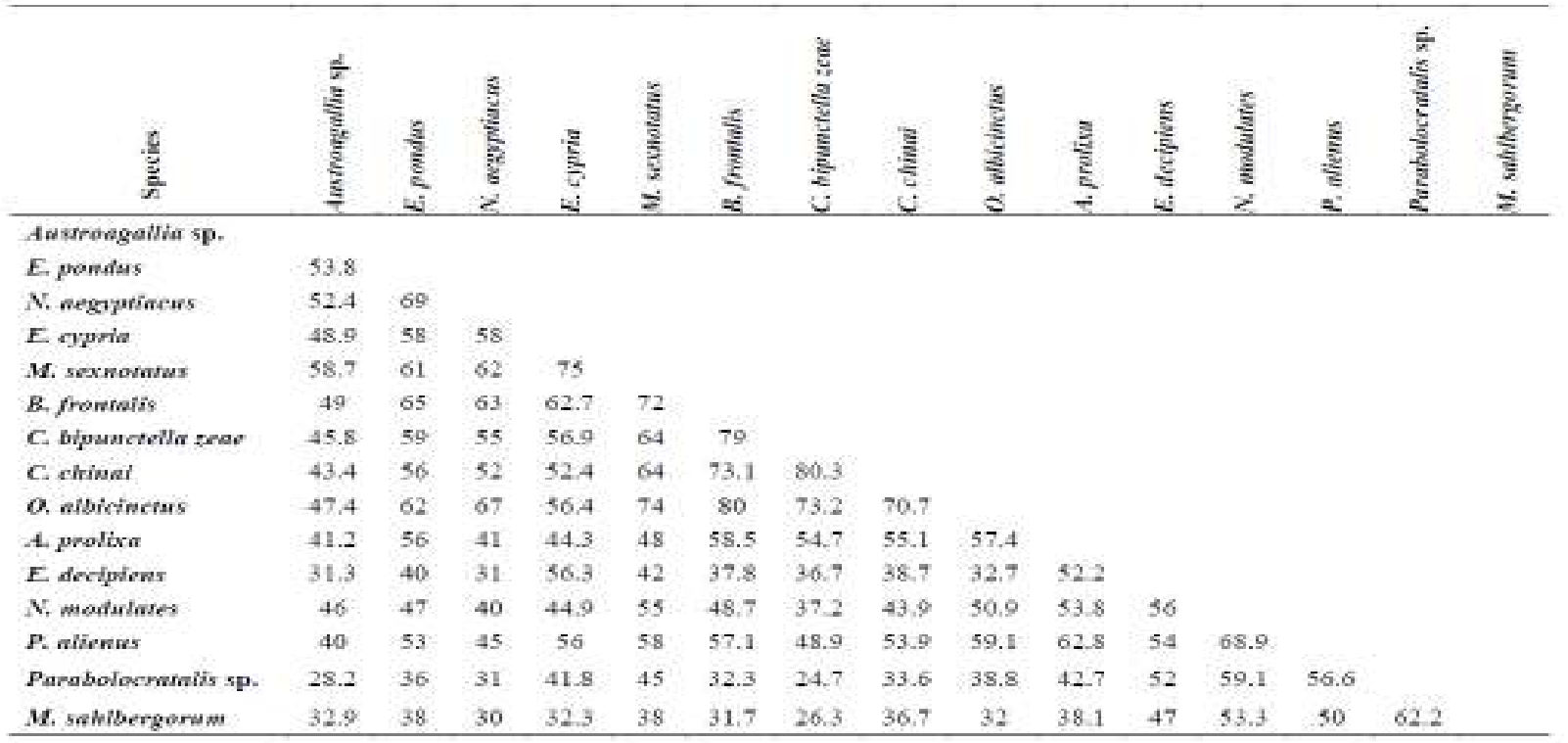

Fig . 2. Dendrogram of phylogenetic relationships for the fifteen leafhopper species based on morphological characters and seven ISSR-PCR markers analysis.

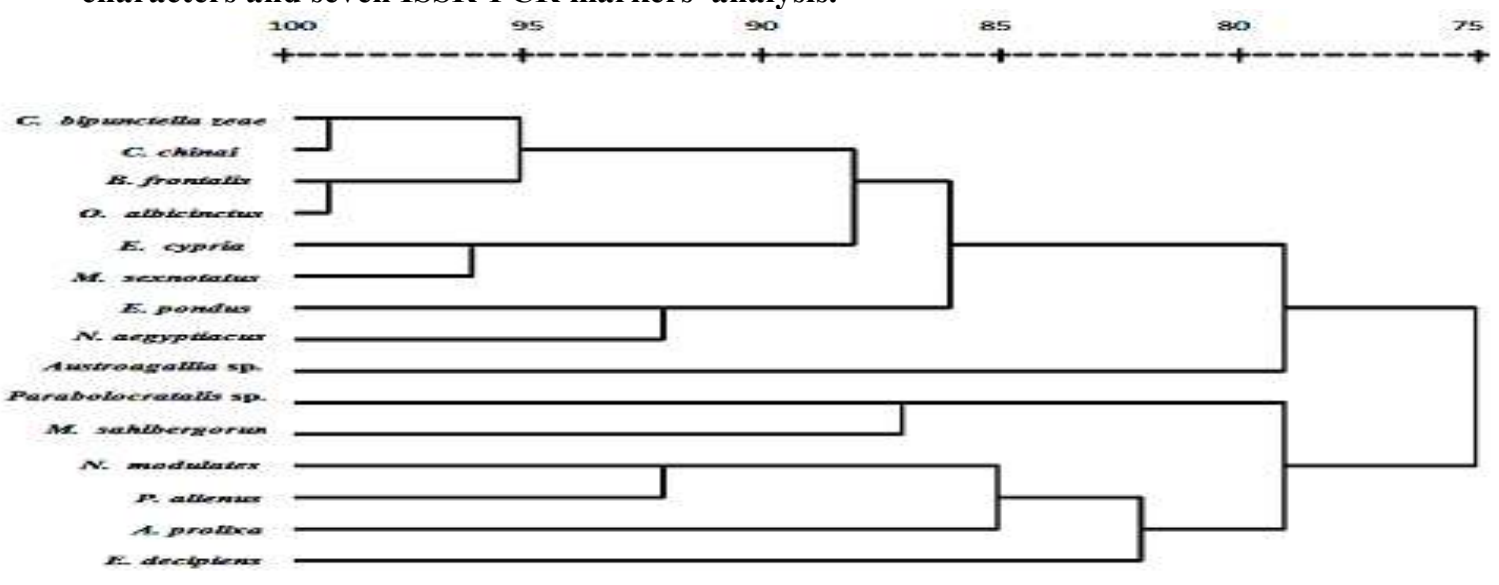

\section{CONCLUSION}

Molecular fingerprint of fifteen leafhopper species collected from different medicinal and aromatic plants in Egypt were carried out using ISSR-PCR technique. This technique successfully generated many molecular markers for different leafhopper species; therefore they could be assigned leafhopper species and to differentiate among them in any life stage. This technique in addition to diagnostic morphological characters could be used to detect the Phylogenetic relationship among the fifteen leafhopper species.

\section{REFERENCES}

Abbot, P. (2001). Individual and population variation in invertebrates revealed by Inter-simple Sequence Repeats (ISSRs). J. Insect Sci., 1(8): 1-3.

Ardeh, M. J. (2013). The utility of ISSR-primers to make difference among populations of parasitoid, Eretmocerus mundus Mercet (Hymenoptera: Aphelinidae). J. Crop Prot., 2 (3): 263-269.
Blair, M. W.; O. Panaud and S. R. McCouch (1999). Inter-simple sequence repeat (ISSR) amplification for analysis of microsatellite motif frequency and fingerprinting in rice (Oryza sativa L.). Theor. Appl. Genet., 98: 780-792.

Charters, Y. M., Robertson, A., Wilkinson, M. J. and Ramsay, G. (1996). PCR analysis of oilseed rape cultivars (Brassica napus L. Ardeh ssp. oleifera) using $5[1]$-anchored simple sequence repeat (SSR) primers. Theoretical and Applied Genetics, 92: 442-447.

Clausing G.; K.Vickers and J.W. Kadereit (2000). Historical biogeography in a linear system: genetic variation of Sea Rocket (Cakilemaritima) and Sea Holly (Eryngium maritimum) along European coasts. Mol. Ecol. 9: 1823-1833.

De León J. H. and W.A. Jones (2004). Detection of DNA Polymorphisms in Homalodisca coagulata (Homoptera: Cicadellidae) by Polymerase Chain Reaction - based DNA Fingerprinting Methods. Annals of the Entomological Society of America 97: 574-585. 
De León J.H. , W.A. Jones and D.J.W. Morgan (2004). Population genetic structure of Homalodisca coagulata (Homoptera: Cicadellidae), the vector of the bacterium Xylella fastidiosa causing Pierce's disease in grapevines. Annals of the Entomological Society of America 97: 809-818.

De Mandal, S.; L. Chhakchhuak; G. Gurusubramanian and N. S. Kumar (2014). Mitochondrial markers for identification and phylogenetic studies in insects - a review. DNA Barcodes, 2(1): 1-9.

Dietrich, C. H. (2005). Keys to the families of Cicadomorpha and subfamilies and Tribes of Cicadellidae ( Hemiptera: Auchenorrhyncha). Fla. Entomol., 88 (4): 502 - 517.

Dietrich, C. H. (2013a). Overview of the Phylogeny, Taxonomy and diversity of leafhopper (Hemiptera: Auchenorrhyncha: Cicadomorpha: Membracoidea: Cicadellidae) vectors of plant pathogens. Proc.2013International Symposium on Insect Vector and Insect-Borne Diseases:4770.

Ebesu, R. H. (2004). Hopper burn on papaya caused by the stevens leafhopper. College of Trop. Agric. Human Resour. (CTAHR) Univ. Hawaii at Manoa, Honolulu, Ins. Pests, 15: 1-2.

Helmi, A. and A. F. Khafaga (2001). Molecular fingerprinting of certain aphids in Egypt (Hemiptera: Sternorrhyncha: Aphididae) using RAPD and ISSRs markers. J.Entomol., 8(4): 327-340.

Herakly, F. A. (1970). Studies on certain jassids infesting vagetables in Egypt. M.Sc. Thesis, Fac. Agric. Ein Shams, Univ., Egypt. 221pp.

Hess, J.; J. W. Kadereit and P. Vargas (2000). The colonization history of Olea europaea L. in Macaronesia based on internal transcribed spacer 1 (ITS-1) sequences, randomly amplified polymorphic DNAs (RAPD), and intersimple sequence repeats (ISSR). Mol. Ecol., 9: 857-868.

Knight, W. J. (1983). The leafhopper genus Batracomorphus (Cicadellidae, Iassinae) in the eastern Oriental and Australian regions. Bull. Br. Mus. Nat. Hist. Ent., 35: 27-210.
Kostia S.; M. Ruohonen-Lehto; R. Vainola and S.L.Varvio, 2000. Phylogenetic information in inter-SINE and inter-SSR fingerprints of the Artiodactyla and evolution of the BovtA SINE. Heredity 84: 37-45.

Luque, C.; L. Legal; H. Staudter and M. Wink (2002). ISSR (Inter Simple Sequence Repeats) as genetic markers in Noctuids (Lepidoptera). Hereditas, 136: 251-253.

Moreno, S., J. P. Martin and J. M. Ortiz, 1998. Intersimple sequence repeats PCR for characterization of closely related grape vine germplasm. Euphytica, 101: 117-125.

Pires, A.C. and L. Marinoni (2010). DNA barcoding and traditional taxonomy unified through integrative taxonomy: a view that challenges the debate questioning both methodologies. Biota Neotrop., 10(2): 339-346.

Reddy K.D.; J. Nagaraju and EG. Abraham, 1999. Genetic characterization of the silkworm Bombyx mori by simple sequence repeat (SSR)anchored PCR. Heredity 83: 681-687.

Sreejith, K. and C. D. Sebastian (2015). Molecular phylogeny and genetic analysis of green leafhopper - Nephotettix virescens (distant) using mitochondrial COI gene. Indian J. Sci. Tech., 8(1): 61-64.

Weintraub, P. G. and L. Beanland (2006). Insect vectors of phytoplasmas. Ann. Rev. Entomol., 51: 91111.

Weng, Y., Azhaguvel, P., Michels, G.J. and Rudd, J.C. (2007). Cross-species transferability of microsatellite markers from six aphid (Hemiptera: Aphididae) species and their use for evaluating biotypic diversity in two cereal aphids. Insect Mol. Biol., 16: 613-622.

Yang, X. and C. F. Quiros (1993). Identification and classification of celery cultivars with RAPD markers. Theor. Appl. Genet., 86: 205-212.

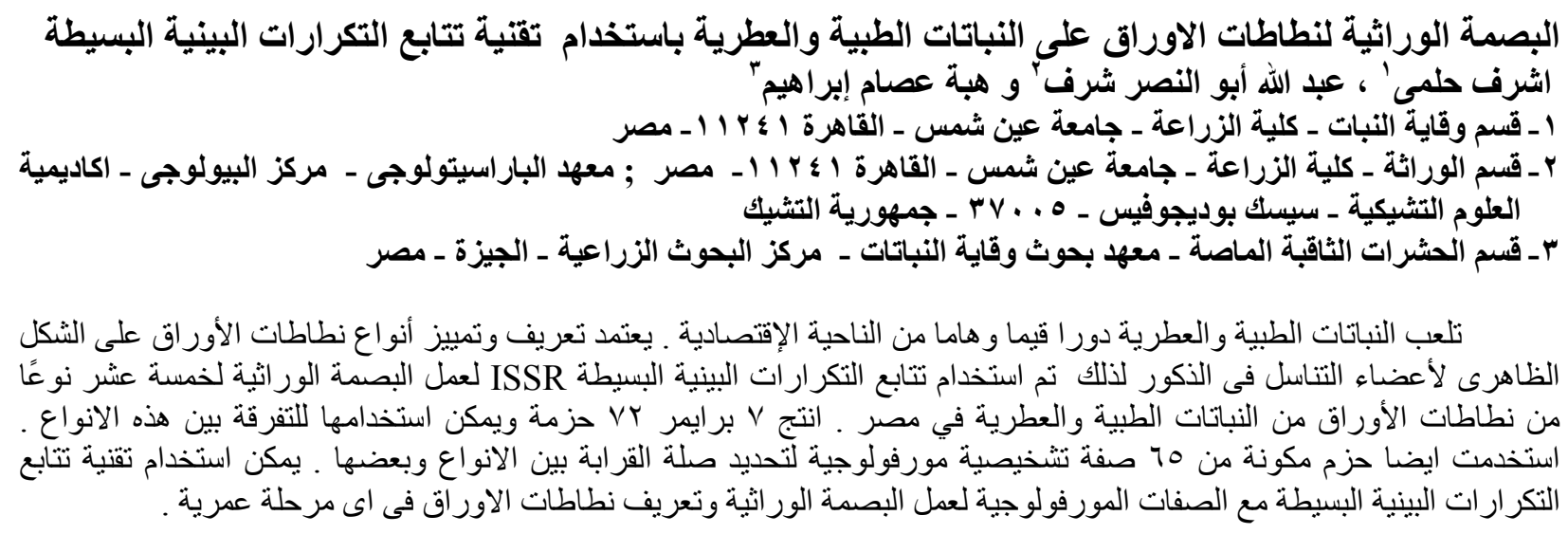

